\title{
Age of Austerity Celebrity Expertise in UK Reality Television
}

\author{
Hannah Hamad*
}

King's College London, UK

Indicative of a growing cynicism towards the figure of the celebrity expert, in April 2011 British TV critic Julia Raeside proposed that it was "time for a rain check" on what she viewed as the spurious celebrity expertise permeating the UK's cultures of reality TV (Raeside 2011). The emergence of recessionary culture in the aftermath of the 2008 financial crisis has affected the cache of the figure of the celebrity expert on UK reality TV in numerous ways, both detrimental and beneficial. Correspondingly, as Helen Powell and Sylvie Prasad contend, the form and function of the celebrity lifestyle expert has become problematic in light of the transformed post-2008 economic environment (Powell and Prasad 2010, p 121). Conversely though, it has enabled the rise to public visibility of new reality celebrities, whose expertise in areas germane to recessionary priorities is efficaciously harnessed in the production of their personae, and the negotiation of the urgent need for their knowledge and skills to be showcased in the public sphere. Employment expert Hayley Taylor of Channel 4's The Fairy Jobmother (2010-) was one such figure to emerge. It has also, in some cases, heightened the discursive traction around extant reality TV experts, whose gleefully consumerist pre-recession celebrity is appositely re-attuned to the transformed economic environment, in an ostensible spirit of responsible recessionary citizenship. For example, the celebrity of retail expert Mary Portas might have struggled to seem relevant in a recessionary climate, given the centrality of the boutique shopping experience, and of the enjoyment of luxury consumer goods to her early public persona, established in her inaugural reality TV vehicle, the BBC's Mary Queen of Shops (2007). Instead though, her recessionary efforts to revitalize

\footnotetext{
*Email: hannah.hamad@kcl.ac.uk
} 
the UK's struggling retail sector, and her shift in recent years towards thrift and sobriety by focusing first on used goods in Mary Queen of Charity Shops (2009), and later the depressed UK manufacturing industry in Mary's Bottom Line (2012), have made her a household name and a ubiquitous presence on British television.

However, notwithstanding the extent to which these examples suggest a level of adeptness in reality TV culture's ability to accommodate shifting social and economic ground into its neoliberal discourse of celebrity expertise, there have also been noteworthy instances that suggest otherwise. In some cases, the public appeal of formerly beloved celebrity experts has waned or wavered, as they struggle to negotiate a discourse apparently at odds with the revised priorities of the recessionary climate. A recent blip in the heretofore highly successful reality TV careers of property market consultants Kirstie Allsopp and Phil Spencer is a noteworthy case in point. Kirstie and Phil (as they are commonly known) are the duo of celebrity experts who front the immensely popular reality series Location, Location, Location (2000-), a show which has aired in the UK for thirteen years so far, over seventeen series, and in which the pair provide counsel to prospective property buyers seeking to purchase homes. Its continued longevity has thus enabled Kirstie and Phil to remain viable public figures in the series that originated their celebrity. The unlikelihood of the pair's continuing appeal comes into sharp focus given the centrality of the collapsed property market to the economic crisis that occurred in the show's ninth year of production. Further, discursive scuttlebutt circulating around them in the UK press and elsewhere, suggested that Kirstie and Phil, and by implication the producers of the series, were complicit in perpetuating the culture of irresponsible borrowing that brought the crisis about (Moir 2003; Cohen 2009), by encouraging their subject participants to purchase homes that it was beyond their means to pay for. This is, of course, to place far too great a deterministic emphasis on the influence of the show's celebrity figureheads in the face of far greater 
contextual forces simultaneously at work. Nonetheless, bearing in mind that the premise of the series relies upon their ability to persuade their subject participants to purchase property, and given the curtailed extent to which people in Britain were purchasing property, after 2008 some critics were left questioning the relevance of a programme like Location, Location, Location to audiences in recessionary Britain, as well as the continued appeal of Kirstie and Phil.

For example, during the broadcast of the show's fourteenth series in 2011, Stuart Heritage, blogging his views on current television for The Guardian newspaper, bemoaned the show's perpetual presence in the schedules, while observing what he perceived to be the broader decline of the property market subgenre of reality TV. He noted that rival series Property Ladder (2001-2006) and $A$ Place in the Sun (2000-2007) had already lost their cache, with the celebrity status of presenters Sarah Beeny and Amanda Lamb considerably diminished as a result (Heritage 2011). ${ }^{1}$ Heritage attributes the ability of Location, Location, Location to buck this recessionary trend in part to the persistent popularity of Kirstie and Phil's celebrity double act, and audiences' affective investment in their flirtatious exchanges. Similarly, Jacqueline Wheeler writing in The Radio Times expressed her surprise at the series' continued popularity, writing that it felt like Allsopp and Spencer were "trying to underpin a concept that was gradually sinking into the sand" (Wheeler 2011). However, with audiences, if not critics, apparently still prepared to accept Location, Location, Location's now all but anachronistic premise, in 2011 Kirstie and Phil were wheeled out again to front the latest in a line of spin-offs. These sister series were heretofore all similarly anchored by the pair's ostensible property market expertise, but a different tack was taken in Vacation Vacation Vacation (2011), in which they redirect their counsel towards holidaymakers. Perhaps unsurprisingly however, the sight of Kirstie and Phil drinking champagne on the beach, and skiing in St Moritz, struggled to strike a chord with audiences in a 
recessionary Britain blighted by unemployment, home repossessions, economic stagnation and a rising cost of living. Vacation, Vacation, Vacation was cancelled after eight episodes, on the grounds that it "failed to resonate with viewers" (Conlan 2011). Without over-determining the link between the recessionary context and the show's failure, and notwithstanding the gestures made in the series towards ostensibly 'budget' holidays, it is nonetheless clear that Vacation, Vacation, Vacation, and its emphasis on the pleasures of luxury leisure locales, was in discursive tension with the imperatives of austerity culture.

Notwithstanding this recessionary misstep, the continued viability of Kirstie and Phil's property market expertise, as well as the 'austerity celebrity' of the aforementioned reality TV experts, brings into view the persistent viability of their publicly personified discourse of neoliberalism. That this is able to take place amidst economic and social crises that should expose the wrongheadedness of neoliberal cultural logic, is troublingly indicative of the extent to which it is entrenched in cultural consciousness, as well negotiable through the ongoing ideological work of the figure of the reality TV expert. All the same, the long term sustainability of the public shelf lives of the television stardoms of Hayley Taylor, Mary Portas, Kirstie Allsopp and Phil Spencer, and who will best exemplify age of austerity celebrity remains to be seen.

\section{References}

Cohen, N., 2009. Don't Blame it on Kirstie. Standpoint [online], July/August. Available at: http://standpointmag.co.uk/node/1731/full [Accessed 1 December 2012]

Conlan, T., 2011. Channel 4's Vacation, Vacation, Vacation is Cancelled. The Guardian [online], 20 October. Available at: 
http://www.guardian.co.uk/media/2011/oct/20/channel-4-vacation-vacation-vacation [Accessed 1 December 2012]

Heritage, S., 2011. Why Not Kill off Location Location Location? The Guardian

[online], 31 August. Available at: http://www.guardian.co.uk/tv-and-

radio/tvandradioblog/2011/aug/31/location-location-location [Accessed 1 December 2012]

Moir, J., 2007. Can We Blame it All on Kirstie Allsopp? The Telegraph [online], 12 December. Available at:

http://www.telegraph.co.uk/comment/columnists/janmoir/3644673/Can-we-blame-itall-on-Kirstie-Allsopp.html [Accessed 1 December 2012]

Powell, H., and Prasad, S., 2010. “As Seen on TV.” The Celebrity Expert: How Taste is Shaped By Lifestyle Media. Cultural Politics, 6:1, 111-124.

Raeside, J., 2011. Celebrity Experts: Time For a Rain Check. The Guardian [online], 8 April. Available at: http://www.guardian.co.uk/tv-andradio/tvandradioblog/2011/apr/08/celebrity-vacation-vacation-vacation [Accessed 8 February 2012]

Wheeler, J., 2011. Location, Location, Location: From Boom Time to Bust. The Radio Times [online], 28 September. Available at: http://www.radiotimes.com/news/201109-28/location-location-location-from-boomtime-to-bust [Accessed 1 December 2012]

\footnotetext{
${ }^{1}$ In fact, the premise of Property Ladder was fairly successfully augmented to account for the transformed economic environment, becoming Property Snakes and Ladders in 2009.
} 